wider range, cthcreal, alliaccous, hircine and nauseating odours all tcing more or less attractive.

The range of the Diptera is exceptionally wide, embracing cthcrcal, fragrant, alliaceous, hircine and nauseating odours. Certain species of mosquitoes, bee flies, and syrphus flies are found fecoing nectar. Eristalis tenax visits cesspools, dung-pits and dccaying vegetable matter in addition to different flowers. Drosophiidæ visit decaying fruits both for food and egg deposition, and Piophila casei is drawn toward chcese, ham and partly spoiled vegetable matter; while the house fly, as everyone knows, shuns r.cthing except aromatic and virulent odours.

Robertson's records show clearly that the Hymenoptera and Diptcra are especially fond of fragrant odours. He found that Pastinaca sativa was visited in twenty-six days by 173 Hymenoptera, 72 Diptera, 14 Colcoptera, 9 Lepidoptera, 6 Hemiptera and 1 Neuropteron; also that Asclepias verticillata was visited by 52 Hymenoptera, 42 Diptera, 16 Lepidoptera and 3 Coleoptera.

It would be extremely interesting to find the effect of exhaustion upon the end argans of smell. A bee, for instance, visiting innumerable flowers of the honeysuck'e must have its organ fatigued by the continuous smelling of this one odor. How, then, would it react to other odours? Does its physiological mechanism of smell cansist of distinct parts, one of which might be put temporarily out of commission without impairing the others, or does it consist entirely of one part?

\title{
THREE NEW GALL MIDGES (DIPTERA).
}

\section{BY E. P. FELT, ALBANÝ, N.Y.}

The following descriptions are of species which have been reared and of one concerning which we possess some exceptionally interesting data. There is much to be learned about our tropical or subtropical midge fauna. There must be hundreds of interesting and undescribed species existing in the West Indies and adjacent countries.

Karschomyia cocci, n. sp.

The midges described below were reared from a sugar-cane mealy bug, Pseudococcus sacchari (?) collected at Central Providencia, Patillas, P.R., January 30, 1913, by 'Mr. D. L. Van Dine. 
The type species of this genus, $K$. viburni Felt is easily distinguished by the almost trinodose character of the flagellate antennal segments of the male; while the only other known species, the Peruvian $K$. townsendi Felt, has much more slender flagellate antennal segments in the male, the stems in this latter each having a length $31 / 2$ times their diameter. Described from specimen in alcohol.

Male.-Length, $1 \mathrm{~mm}$. Antennæ; $1 / 4$ longer than the body, rather thickly haired, yellowish brown; 14 segments, the fifth having the stems with a length $1 \frac{1}{2}$ and two times their diameters, respectively; circumfili and setæ well developed. Palpi: First segment short, subquadrate; the second with a length three times its diameter, the third $1 / 2$ longer, more slender; the fourth $1 / 2$ longer than the third. Mesonotum dark brown, the submedian lines fuscous yellowish. Scutellum and postscutellum yellowish. Abdomen yellowish white, the dorsal sclerites and genitalia somewhat fuscous. Halteres pale yellowish. Coxæ and femora mostly pale yellowish; tibiæ and tarsi fuscous yellowish. Claws slender, strongly curved, the anterior unidentate, the pulvilli rudimentary. Genitalia: basal clasp segment moderately stout, the posterior external angles somewhat produced and bearing a group of three or four stout setæ; terminal clasp segment subapical, swollen near the middle, curved; dorsal plate long, deeply and narrowly emarginate, the lobes broad, narrowly rounded.

Female.-Length, $1.5 \mathrm{~mm}$. Antennæ extending to the third abdominal segment, sparsely haired, dark brown; 14 segments, the fifth with a stem about $1 / 4$ the length of the cylindric basal enlargement, which latter has a length about twice its diameter; terminal segment produced, the enlargement with a length three times its diameter and apically a broad, knoblike appendage. Mesonotum dark brown, submedian lines indistinct. Scutellum and postscutellum yellowish. Abdomen yellowish orange, the dorsal sclerites somewhat fuscous. Ovipositor short, yellowish, the terminal lobes narrowly oval. Halteres: Coxæ and femora mostly pale yellowish; tibiæ and tarsi light straw. Type, Cecid a2415.

Mycodiplosis insularis, n. sp.

This midge was reared from a vial containing leaves of Leonnotis nepetæfolia abundantly infested with red spider. There 
were also small, white coccons among the colonics of red spider collected at Pio Piedras, P.R., August 6, 1913, by Thcmas H. Jones. This species appears to be allied to $M$. reducta Felt, from which it is most easily separated by its larger size and the somewhat longer distal stem of the 5 th antennal segment. Described from specimens in alcohol.

Larva.-Length, $1.3 \mathrm{~mm}$; moderately stout, pale yellowish. Head apparently with a length nearly twice its diameter, broadly rounded anteriorly. Antennæ long, with a length fully 10 times the diameter, slender, curving, posterior extremity subtruncate and irregularly papillate.

Male.-Length, $1 \mathrm{~mm}$. Antennæ, $1 / 4$ longer than the body, sparsely haired, light brown; 14 segments, the 5 th having the stems with a length $1 \frac{1}{2}$ and $2 \frac{1}{2}$ times their diameters, respectively; circumfili well developed. Palpi: the first segment short, subquadrate, the second with a length twice its diameter, the third a little longer, more slender, the fourth $1 / 2$ longer than the third. Mesonotum dark reddish brown, the narrow submedian lines yellowish. Scutellum and postscutellum pale yellowish. Abdomen mostly pale yellowish, the dorsal sclerites slightly fuscous. Halteres, coxæ and femora mostly pale yellowish, tibiæ and tarsi light straw. Claws slender, strongly curved, the pulvilli as long as the claws. Genitalia: basal clasp segment maderately stout, terminal clasp segment swollen basally, slightly curved; dorsal plate moderately long, deeply and roundly emarginate, the lobes narrowly rounded.

Female-Length, $1.25 \mathrm{~mm}$. Antennæ extending to the second abdominal segment, sparsely haired, light brown; 14 segments, the fifth with a stem $1 / 4$ the length of the cylindric basal enlargement, which latter has a length $2 \frac{1}{2}$ times its diamcter; terminal segment slightly produced, with a length thrce times its diameter, broadly rounded apically. Face yellowish brown. Ovipositor short, yellowish, the lcbes narrowly oval. Type, Cecid a2413.

Clinodiplosis examinis, n. sp.

The midges described below were present by hundreds, if not thousands, upon a screen dcor, or hanging from cobwebs attached thereto at Nassau, N.Y., June 19, 1913. The insects were so 
numerous as to fairly cot the surface of the screen here and there, and where spider webs occurred it was rot uncommon to see 5 or 6 in a line usually atout a quarter of an inch apart. They hung lightly from the web, were easily disturbed and frequently returned to their fragile supforts. ${ }^{*}$ The insects were so numerous that it was comparatively easy to capture some 50 with an ordinary collecting tottle by simply placing it over groups of three or four kere and there on the scrcen. The midges had rot keen observed previously and presumably represent the emergence of a brced from scme nearby fecd plant or fcod material, possibly plant lice inhabiting adjacent maple or elm trees.

Male.-Length, $1 \mathrm{~mm}$. Antennæ fully $1 / 2$ longer than the tody, thickly kaired, light brown; 14 segments, the fifth having the two portions of the stems 3 and $3 \frac{1}{2}$ times their diameters, respectively; the distal enlargement with a length $3 / 4$ greater than its diameter and a slight constriction near the basal third. Palpi: first segment subquadrate, with a length fully twice its diameter; the second a little longer, more slender; the third nearly twice the length of the second, somewhat dilated; the fourth a little longer than the third, more slender. Mesonotum yellowish brown. Scutellum brownish yellow, post scutellum fuscous yellowish. 'Abdomen mastly reddish brown, the genitalia reddish yellow. Costa fuscous straw. Halteres mostly yellow transparent, slightly fuscous subapically; Caxæ and femora mostly pale yellowish, the tibiæ and tarsi fuscous straw; claws slender, strongly curved, the anterior unidentate, the pulvilli about half the length of the claws. Genitalia: basal clasp segment moderately stout; terminal clasp segment long, slightly swollen basally; dorsal plate stort, broad, deeply and triangularly emarginate, the lobes broadly rounded; ventral plate long, rather broad, broadly and roundly emarginate, the lokes st.ort and with a few coarse setæ apically; style long, stout, tapering.

Female: Length, $1.5 \mathrm{~mm}$. Antennæ nearly as long as the tody, sparsely haired, reddish brown; 14 segments, the fifth with

*Mr. Frederick Knab (N.Y. Ent. Soc. Journ. 20: 143-46) records a number of Diptera as habitually occuring on spider's webs. In this connection it is worihy of note that Mr. D. B. Young found last June at Albany N. Y. a Tipulid hanging on cobwebs, leaving and returning thereto at will. The species appears identical with a specimen in the state collection determined by Mr. C. P. Alexander as Oropega obscura. 
a stem nearly $3 / 4$ the length of the cylindric basal enlargement, which latter has a length atout twice its diameter; terminal segment produced, the basal enlargement cylindric, with a length more than three times its diameter and apically a finger-like process. Palpi: first segment subquadrate, with a length more than twice its diameter, the second twice the length of the first, the third a little longer, somewhat dilated; the fourth a little longer and more slender than the third. Mesorotum slaty brown, the submedian lines indistinct. Scutellum yellowish, fostscutellum fuscous yellowish. Abdomen brownish red, the dorsal sclerites somewhat fuscous. Ovipasitor reddish yel!ow. Halteres yellowish transparent, fuscous subapically. Coxæ pale yellowish, ferora light straw, tibiæ and tarsi fuscous straw. Ovifcsitor stout, nearly as long as the abdomen, the terminal lobes lanccolate, sparsely setose. Type, Cecid a 2411.

Described from a number of males and females taken together and presumably specifically identical.

\section{A NEW SPECIES OF HELIOTHRIPS (THYSANOPTERA) FROM MARYLAND AND ILLINOIS.}

BY $\mathbf{j}$. DOUGLAS HOOD,

United States Biological Survey, Washington, D. C.

The systematist's interest in the genus Heliothrips Haliday is enhanced by the fact that it includes several of the best krown and most troublesome species of the order. Hamorrhoidalis and femoralis are cosmopolitan greenhouse pests ; rubrocinctus, a widely distributed tropical species, injurious to cacao, has lately appeared in Florida as an enemy of the mango and avocado; fasciatus often proves troublescme to keans and cther crops in California ; while the recently described phaséoli is an imfortant bean pest in southernmost Texas.

In a recent paper on the genus, ${ }^{*}$ Dr. Karny unites Dictyothrips and Parthenothrips with Heliothrips, recognizing them as subgerera only, and erects a fourth subgenus, Selenothrips, for a new species which he calls decolor and for rubrocinctus Giard. While admitting that Selenothrips is a well-founded subgenus, I can rot follow Dr. Karny in his treatment of Dictyothrips and Parthenothrips. In the

*Revision der Gattung Heliothrips Haliday, Ent. Rundsch., 28 Jhg., no. 23, pp. 179-182, 5 figs.; 1911.

September, 1913 


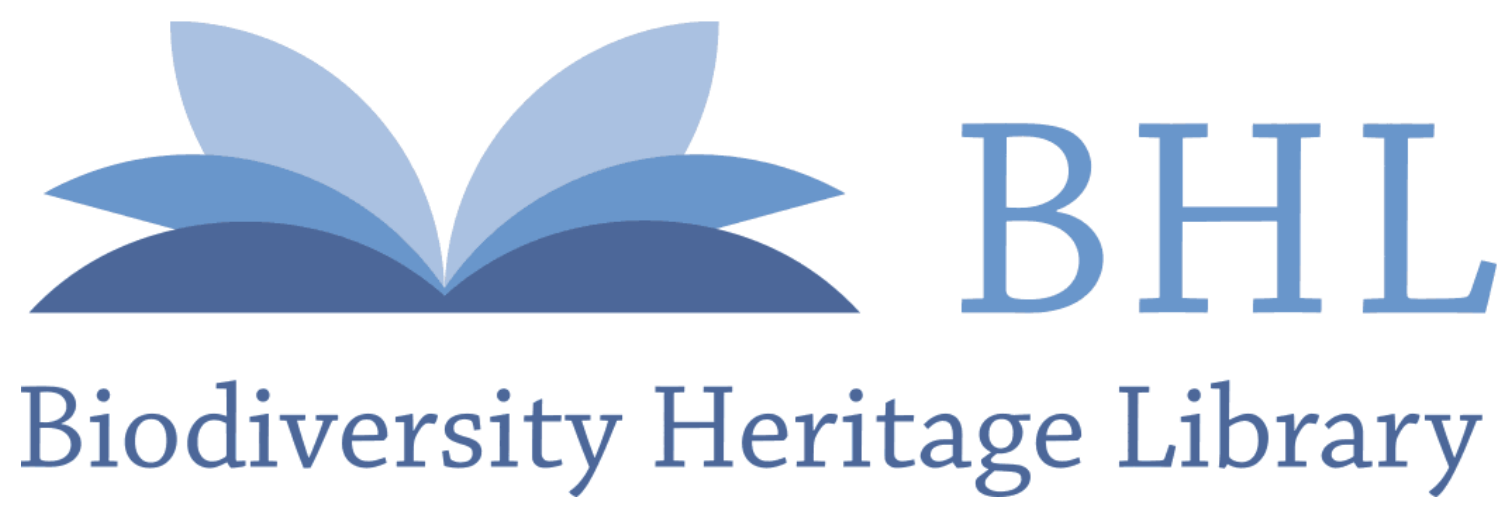

Felt, Ephraim Porter. 1913. "Three new gall midges (Diptera)." The Canadian entomologist 45, 304-308. https://doi.org/10.4039/Ent45304-9.

View This Item Online: https://www.biodiversitylibrary.org/item/22231

DOI: https://doi.org/10.4039/Ent45304-9

Permalink: https://www.biodiversitylibrary.org/partpdf/27103

\section{Holding Institution}

MBLWHOI Library

Sponsored by

MBLWHOI Library

\section{Copyright \& Reuse}

Copyright Status: NOT_IN_COPYRIGHT

This document was created from content at the Biodiversity Heritage Library, the world's largest open access digital library for biodiversity literature and archives. Visit BHL at https://www.biodiversitylibrary.org. 